\title{
Nevâî ile Fuzûlî’nin Leylâ ve Mecnûn Mesnevilerinin Yapı ve Konu Bakımından Karşılaştırılması
}

\author{
İbrahim AKYOL*
}

Öz

Edebiyat bilimi yapısı ve işlevi gereği birçok bilim dalıyla etkileşim halindedir. Edebiyatın bir alt birimi olan Karşılaştırmalı Edebiyat, kültürlerarası etkileşimin edebî eserlere yansıyan yönlerini araştırıp ortaya çıkarır. Karşılaştırmalı Edebiyat, edebî eserleri konu, düşünce ve biçim açısından inceleyerek benzer ve farklı yönlerini ortaya koymaktadır.

Klasik Türk Edebiyatı'nın mesnevi konularından olan Leylâ ve Mecnûn hikâyesi önce Arap edebiyatında Kays b. Mülevvah el-Âmiri ile ortaya çıkmış, daha sonra Fars, Türk ve Urdu edebiyatlarında işlenmiş ve işlenmeye de devam etmektedir. Türkçede ilk müstakil Leylâ ve Mecnûn hikâyesini 1479'da yazan Edirneli Şâhidi'dir. Bu incelemede; 15. yüzyılda yaşamış ve Çağatay Türkçesinin en büyük şairi kabul edilen Ali Şîr Nevâ̂'’nin 1484'te yazdığı Leylî vü Mecnûn mesnevisi ile 16. yüzyılın en büyük şairlerinden olan Fuzûlî’nin 1537'de tamamladığı Leylâ ve Mecnûn mesnevisi iki açıdan karşılaştırılmıştır. Mesnevilerin önce özetleri verilmiş, daha sonra yapı bakımından (şekil, vezin, kafiye ve redif ) ve konu bakımından (vak'a farklılıkları, birinde olup diğerinde olmayan vak'alar) karşılaştırılmıştır. Elde edilen neticeler sonuç kısmında değerlendirilmiştir.

Anahtar Kelimeler: Karşılaştırmalı Edebiyat, Klasik Türk Edebiyatı, Leylâ ve Mecnûn, Ali Şîr Nevâî̂, Fuzûlî, Mesnevi.

\footnotetext{
* Dr. Öğretim Üyesi, Çankırı Karatekin Üniversitesi, Edebiyat Fakültesi, Türk Dili ve Edebiyatı Bölümü, Çankırı, Türkiye Elmek: iakyo118@karatekin.edu.tr. https://orcid.org/0000-0002-8363-592X
} 


\title{
The Comparison of the Layla and Majnun Masnavis of Navai and Fuzuli in Terms of Form and Content
}

\begin{abstract}
The science of literature has been interacting with many disciplines due to its structure and function. The comparative literature, which is a sub-unit of literature, seeks and reveals the aspects of intercultural interaction reflected in literary works. Comparative Literature examines literary works in terms of content, thought and form and puts forward similar and different aspects.

The story of Layla and Majnun, which is among the Masnavi subjects of Classical Turkish Literature, was firstly arose with Kays b. Mawlawah al-Amiri in Arabic literature, later handled in Persian, Turkish and Urdu literatures and keeps being handled. The first independent Layla and Majnun story was written by Sahidi of Edirne in Turkish language in 1479. In this research, the Masnavi of Layla and Majnun written in 1484 by Ali Shir Navai, who lived in the 15th century and was accepted as the greatest poet of Chagatai Turkish and the Masnavi of Layla and Majnun completed in 1537 by Fuzuli, one of the greatest poets of the 16th century, were examined in two aspects. The summaries of the masnavis were provided firstly, then they were compared in terms of form (structure, meter, rhyme and repeated words) and content (case differences, and the cases in one but not the other). The obtained results were evaluated in the conclusion part.
\end{abstract}

Keywords: Comparative Literature, Classical Turkish Literature, Layla and Majnun, Ali Sir Nevai, Fuzuli, Masnavi. 


\section{Extended Summary}

This article comprises the comparison of Layla and Majnun Masnavis of Ali Sir Nevai and Fuzulu, two greatest poets of Turkish Literature, in terms of form and content. The aim of this study is to compare these two masnavis, which were written 50 years apart from each other, in terms of form and content and then to provide a basis for a wide comparison from different aspects.

In this study, based on the literary work, it is aimed to determine whether Ali Sir Nevai, the greatest poet of Chagatai Turkish Literature in 15th century, has an influence on Fuzuli, one of the greatest poets of the 16th century. Of course, in order to retain such an influence, the works of the aforementioned poets should be examined from various aspects.

In this research, the scientific publication of Ali Sir Nevai's Layla and Majnun Masnavi by Ülkü Çelik (Turkish Language Association, Ankara-1996), the scientific publication of Fuzuli's Layla and Majnun Masnavi by Muhammet Nur Doğan (Yapı Kredi Publications, Istanbul-2004) and Agah Sirrı Levend's work called Layla and Majnun in Arabic, Persian and Turkish Literature (Turkish Historical Society, Ankara-1959) were assigned as the main sources. Apart from these, the cited works are as follows: Arzu Atik, The Comparison of Layla and Majnun by Celili and Layla and Majnun by Nizami (Istanbul-2009), Gürsel Aytaç, Comparative Literature (Ankara-1997), Yavuz Bayram, "Comparative Literature and and An Application of it" Journal of Turkish Research (Konya-2004), Pervin Capan, (2005) "The Comparative Analysis of the Phrase of the Layla and Majnun Masnavis of Ali Sir Nevai and Fuzuli”, (Eskişehir -2003), İsmail Durmuş, "Layla and Majnun" (Istanbul-2003), İlhan Genc, The two poets of Layla and Majnun: Fuzuli and Sezai Karakoc (Istanbul-2005), Nurgul Karayazı, Sufi Concepts and Elements in Layla and Majnun of Fuzuli (Istanbul2007),Emel Kefeli, “Comparative Literature: Its Definition, Method and Reviews," (Istanbul-2006) Kutuk Rifat, the Layla and Majnun Masnavi by Hamdi of Larende and its comparison with the other Layla and Majnun Masnavis (Erzurum-2002), Hasibe Mazıoglu, Fuzuli-Hafiz (Ankara-1956), Ebru Senocak, 
A Comparative Research on the story of Layla and Majnun, (Elazig- 2000), Lokman Turan, Reading Masnavi with lyrics, (Istanbul-2017), Ismail Unver, "Masnavi," Turkish Language Divan Poetry Special Issue (Ankara-1986), Nazir Akalın, The Argumentative Comparison of the Layla and Majnun Masnavis by Nizami Ganjavi and Fuzuli of Baghdad, Seljuk Research Journal (Konya-1997).

In the literature review, it was seen that there is a study titled "Comparative Analysis of the Phrases of the Layla and Majnun Masnavis of Ali Shir Navai and Fuzuli" and no other study comparing Fuzuli and Nevâi with different aspects was found. However, it is seen that masnavis belonging to other poets are compared. The results obtained from the literature review concluded that the masnavis of these two poets should be compared in every aspect and as a next step, the comparison of these two masnavis in terms of form and content has started.

Comparison is the methodology of this study. It was tried to reach some results by comparing both the masnavis in terms of form and content. Firstly, theoretical information about comparative literature was given, then the situations of Layla and Majnun Masnavi in Arabic, Persian and Turkish literature are briefly mentioned. At this stage of the study, the extended summaries of the both masnavis are provided, later they were compared in terms of structure, meter, rhyme and repeated words. In the comparison of the content, case differences in both masnavis and cases in one but not in the other were determined. The results obtained from the comparison are indicated in the conclusion part. Comparative literature can be used not only for the works written in different languages, but also in the same language. The story of Layla and Majnun is handled in Arabic, Persian, Turkish and Urdu literatures. Although the whole work of Nevai was written in verses, $92 \%$ of Fuzuli were written in the verses and the rest of it was written in the forms of ode, lyric and quadrate. Nevai used the form of "sekt-i melih" of aruz prosody, Fuzuli used the other aruz prosody forms beside this form. It is seen that not only are there differences in cases, but also there are cases in one but not in the other in both masnavis.

It is seen as a result of the comparison that Fuzuli's Masnavi is more durable in form, richer and more varied in terms of content than Ali Sir Nevai's Masnavi. It is concluded that Fuzuli used the material more successfully. In this case, it is possible to say that Fuzuli read Nevai's Masnavi but he did not take it as a model. 


\section{Giriş}

Bir bilim dalı olarak edebiyat, yapısı ve işlevi gereği birçok disiplinle etkileşim halindedir. Aynı zamanda edebiyat, birçok alanla da ilişkili olup bunlardan birisi de "Karşılaştırmalı Edebiyat"tır. "Karşılaştırmalı edebiyat, kültürler arası etkileşimin edebî eserlere yansıyan yönlerini araştırarak edebiyat tarihi, sosyal tarih ve kültürel değişim tarihine 1şık tutmayı hedefleyen bir alandır. Tercüme, tesir, imge ve tipoloji çalışmaları, yazarların okuma kültürleri, farklı kültür ve edebiyatlarla ilişkileri, millî kültürler ile yabancı kaynaklar arasındaki alış veriş gibi karşılaştırmalı edebiyat araştırmaları son derece hassas ve araştırmacının kesin hükümler vermesini engelleyen kaygan bir zemin üzerinde yapılan incelemelerdir.” (Kefeli, 2006:331) “Karşılaştırmalı edebiyat araştırmalarının çıkış noktası, başta klasik eserler olmak üzere insanlığın ortak kültür hazinelerini teşkil eden edebî eserlerdeki müşterek noktaları tespit etmek, dönemlere ve edebî türlere göre karşılaştırarak özellikle ulusal edebiyatların güçlenmesini ve gelişmesini sağlayacak şekilde başka ülkelere, dillere ait edebiyatlardan istifade etmektir. Bu edebiyatın görevi, işlevi farklı dillerde yazılmış iki eseri konu, düşünce ya da biçim bakımından incelemek; ortak, benzer ve farklı yanlarını tespit etmek, bu farklılığın nedenleri üzerine yorumlar getirmektir." (Aytaç, 1997:7) Karşılaştırmalı edebiyat çalışmalarını birden fazla dil ve kültüre mensup edebî eserler arasında olması gerektiğini savunanlar olduğu gibi aynı dil ve kültüre mensup edebî eserler arasında da çalışmaların yapılacağııı savunanlar da bulunmaktadır.

"Edebî metinler tek başına ve bağımsız değildirler. Her metin kendi döneminin başka metinleriyle ya da daha önce yazılmış öteki metinlerle yer yer biçim, içerik, tür ve anlatım özellikleri bakımından alıntı, yakınlık, benzerlik ilişkisi içinde bulunur. Buna göre edebî metinler, sürekli bir ilişki içinde başka metinlerin etkileri ve katkılarıyla ortaya çıkar.” (Uçan Eke, 2013: 2653) Gürsel Aytaç'ın karşılaştırmalı edebiyat çalışmalarına yüklediği fonksiyondan yola çıkarak Yavuz Bayram, edebî metinlerin a) Konu b) Düşünce c) Biçim, açısından 
karşılaştırmalarının yapılabileceğini belirttikten sonra karşılaştırmalı edebiyat incelemesi için aşağıdaki bölümleri teklif etmektedir:

1. Dış yapı (şekil) özellikleri açısından karşılaştırma

2. Edebî tür ve bu türün özellikleri açısından karşılaştırma ${ }^{1}$

3. Edebî çevre, dönem, saha ve akım açısından karşılaştırma

4. Müellif (şair/yazar) açısından karşılaştırma

5. Edebî sanatlar, dil ve anlatım açısından karşılaştırma

6. Bakış açısı, anlatıcı ve hayat felsefesi açısından karşılaştırma

7. Konu, tema, mesaj, motif, tip, ana ve ara fikirler açısından karşılaştırma

8. Kültürel ve sosyal yaşantıyla ilgi açısından karşılaştırma

9. Başka disiplinlerle ilgi açısından karşılaştırma (Bayram, 2004: 70)

$\mathrm{Bu}$ kuramsal bilgilerden yola çıkarak 15. yüzyılda yaşamış ve Çağatay Türkçesinin en büyük şairi kabul edilen Ali Şîr Nevâî'nin (1441-1501) 1484'de yazdığı Leylî vü Mecnûn mesnevisi ile 16. yüzyılın en büyük şairlerinden olan Fuzûlî’nin (1483-1556) 1537'de tamamladığı Leylâ ve Mecnûn mesnevisi yap1 ve konu açısından mukayese edilecektir. ${ }^{2}$

\section{Leylâ ve Mecnûn Hikâyesi}

Hikâye, Arap Edebiyatı'nda Kays b. Mülevvah el-Âmiri'nin lakabı olan Mecnûn'un (ö.70/689) aynı kabileye mensup Leylâ bint Mehdi el-Âmiriyye'ye duyduğu aşk yüzünden aklını kaybetmesi olayına dayanmakta olup bu olay1 esas alarak yapılan yorum ve ilavelerle oluşmuştur (Durmuş, 2003: 159). Nitekim Ali Şîr Nevâ̂̂’nin "Bu Şam fesânesi uzun-dur / Haddin kara kaygusı füzûn-dur" diyerek bu duruma işaret ettiği hikâye (Çelik, 1996; 45) önce Arap debiyatında daha sonra Fars, Türk ve Urdu edebiyatlarında çokça işlenmiş

1 Türk Edebiyatı’ndaki Leylâ ve Mecnûn mesnevilerinin hepsini içine alan edebî tür ve özellikleri açısından yapılacak karşılaştırmalar, mesnevinin nazım şekli mi, nazım türü mü tartışmalarının daha sağlıklı zeminde yapılmasına katkı sağlayacaktır.

2 Bu karşılaştırmada Ülkü Çelik tarafından hazırlanan Ali Şîr Nevâî’nin Leylî vü Mecnûn mesnevisi (Ankara-1996) ile Muhammed Nur Doğan tarafından hazırlanan Fuzûlî’nin Leylâ ve Mecnûn mesnevisi (İstanbul-2004) esas alınmıştır. Beyit numaraları bu iki çalışmaya aittir. 
ve halen de işlenmeye devam etmektedir. Leylâ ile Mecnûn hikâyesi 10. asrın sonlarında Kitâbü'l-Agânî ile İran'a geçmiştir. Bu hikâye Arap halkının ortaya koyduğu anonim bir aşk destanı olduğu halde İran edebiyatında onu ele alan ve dünya çapında büyük bir üne kavuşturan şair, Nizâmî'dir. İran edebiyatı'nda ilk defa Nizâmî tarafından işlenen ve lirik aşk hikâyeciliği konusunda gerçek kıvamına eren hikâye bütün dünya edebiyatlarında günümüze kadar hoş bir sada bırakmıştır (Akalın, 1997: 204). 584/1188'de Nizâmî’nin kaleme aldığ1 bu manzum hikâyeyi (Levend, 1959: 370) ondan başka Emir Hüsrev-i Dehlevî (ö.1325) Abdurrahman-1 Câmî (ö.1493) ve Afîfî (ö.?) gibi şairler de kaleme almıştır. Aynı zamanda bu şairler, Leyla ve Mecnûn hikâyesinin yeniden yorumlanması hususunda Türk şairlerine de ilham kaynağı olmuşlardır (Doğan, 2004: 13). Leylâ ve Mecnûn hikâyesi, gerek Anadolu'da gerekse Anadolu dışında birçok Türk şairi tarafından işlenmiştir. Türk edebiyatında ilk defa Gülşehrî’nin (ö.1350) 713/1313'te yazdığı Mantıku't-tayr'ında 79 beyit olarak görülür (Levend, 1959:103). Âşık Paşa'nın (ö.733/1332) Garibnâmesi'nde ise Allah'a varan gerçek aşk1 anlatmak için 30 beyitte Leylâ ve Mecnûn sembol olarak kullanılır. Bu hikâyeyi Türk dilinde tam olarak nazmedip müstakil bir eser haline getiren şair -bugünkü bilgilerimize göre- Edirneli Şâhidi'dir (ö.1505). Şehzade Cem adına İstanbul'da nazm edilmeğe başlanan eser 883/1479'da Konya'da tamamlanmıştır. Eserin ilk beyti olan "Zükâ-ı matla'-ı eşvâkdur bu / Kitâb-ı Gülşen-i Uşşâkdur bu” beytinden asıl adının Gülşen-i Uşşâk olduğu anlaşılmaktadır. Aruzun "mefâ‘îlün mefâ‘îlün fe ‘ûlün” kalıbıyla yazılan ve 5660 beyitten oluşan eserin en önemli özelliği edebiyatımızda yazılan diğer Leylâ ve Mecnûn mesnevilerinin en hacimlisi olmasıdır (Kartal, 2013: 343).

İsmail Ünver, mesnevilerin tasnifini yaparken Leylâ ve Mecnûn mesnevilerini "sanat yönü ön planda olan okuyucunun edebî zevkine hitap eden ana çizgisi aşk ve macera olan mesneviler" olarak nitelendirip kahramanlarının beşeri aşktan ilahi aşka yükseldiklerini veya kahramanlar arasında aşk bütünüyle beşeri olduğu halde, iki aşığın kavuşmasını tasavvufi mecazlarla örten mesneviler olarak kabul etmektedir. Bu mesnevilerin konularını genellikle Arap ve Fars edebiyatlarından aldıklarını, bunlardan çeviri ya da serbest çeviri olanlar yanında ekleme ve çıkartmalar yapılarak "Türkî libâs giydirilen" mesnevilerin oldu- 
ğunu, bu mesnevilerde şairlerin şiirdeki ustalıklarını, hünerlerini göstermeye çalıştıklarını söylemektedir (Ünver, 1986: 441). Leylâ ile Mecnûn hikâyesi, eski edebiyatın çift kahramanlı aşk hikâyelerinden biri olup Yusuf ile Züleyha'dan sonra en yaygın olanıdır. Leylâ ve Mecnûn mesnevilerinin birbirleriyle çeşitli yönlerden mukayese edildiği çalışmalar yapılmıştır. Hatta Fuzûlî’nin mesnevisi ile Aziz Nesin'in Fuzûlı̂' den ilham alarak mensur olarak kaleme aldığı Leylâ ile Mecnûn halk hikâyesi de karşılaştırılmıştır. ${ }^{3}$

Ali Şîr Nevâî Leylî vü Mecnûn mesnevisinde kendisinin ilham aldığg şairleri söyler:

Efsâneleri cihânda nâmî

Nazm eylep Hüsrev ü Nizâmî (Beyit:573)

Andak ki bolup demekke meyli

Nazm evcining ahteri Süheyli (Beyit:575)

Fuzûlî'nin Leylâ vü Mecnûn mesnevisinde Nizâmî’yi taklit ve terceme edip etmediği iddiaları sıkça tartışılmakla beraber genel kanaat, Fuzûlî’nin Nizâmî’yi esas aldığı yönündedir (Akalın, 1997: 201-210). Dolayısıyla her iki şair de İranlı Nizâmî’den beslenmişlerdir.

Ali Şîr Nevâî’nin Fuzûlî üzerindeki tesiri konusunda Latifî; "Nevâî tarzına karib bir tarz-1 dil-firib ve üslûb-1 acîbi vardır" (Latifî, 2000: 435) ifadesini kullanır. Ahdî ise; "lisân-1 Tâzî'de olan ebyâtı fusahâ-yı 'Arab'da meşhûr güftâr-1 Nevâyi-âyîni Türkân-1 Mogol yanında mezkûr ve zebân-1 Fürs'de olan

3 Leylâ ile Mecnûn hikâyelerini karşılaştırmalı olarak inceleyen -tespit edebildiğimiz kadarıyla- şu çalışmalar yapılmıştır: 1) İlhan Genç, Leylâ ile Mecnûn'un İki Şairi Fuzûlî ve Sezai Karakoç, İstanbul-2005, 352 s. 2) Arzu Atik, Celili’nin Leylâ ve Mecnûn’u ve Nizami’nin Leylâ ve Mecnûn’u İle Karşılaştırma, Marmara Üniversitesi, Türkiyat Araştırmaları Enstitüsü, İstanbul-2009, 427 s. 3) Rıfat Kütük, Larendeli Hamdi’nin Leylâ ile Mecnûn Mesnevisi ve Diğer Leylâ ile Mecnûn Mesnevileriyle Mukayesesi, Atatürk Üniversitesi, Sosyal Bilimler Enstitüsü, Erzurum-2002, 807 s. 4) Ebru Şenocak, Leylâ ile Mecnûn Hikâyesi Üzerine Mukayeseli Bir Araştırma, Fırat Üniversitesi, Sosyal Bilimler Enstitüsü, Elazığ-2000, 338 s. (Bu çalışmada Leylâ ile Mecnûn mesnevisi ile Halk Edebiyatındaki Leylâ ile Mecnûn hikâyeleri karşılaștırılmıştır.) 5) Bayram Çelik, Fuzûlînin Leylâ vü Mecnûn Mesnevisi ile Hamdulllah Hamdi’nin Yusuf u Züleyha Mesnevisinde İnsan Psikolojisi, Çukurova Üniversitesi, Sosyal Bilimler Enstitüsü, Adana- 1998, 133 s. 6) Süleyman Yiğit, (2018) “Fuzûlî ve Aziz Nesin’in "Leylâ ile Mecnûn”larının Mukayesesi” TÜRÜK, Uluslararası Dil, Edebiyat ve Halkbilimi Araştırmaları Dergisi, S.12, s.364394. 7) Nazir Akalın, "Nizami-yi Gencevi ile Fuzuli-yi Bağdadi’nin Leyli u Mecnun Mesnevilerinin Tartışmalı Mukayesesi” Türkiyat Araştırmaları Dergisi, S.3, Konya-1997. 
dîvânı pesendîde-i şu'arâ-yı her merzbûm ve eş'âr-1 Türkîsi makbûl-i zurafâ-yı Rûm olmışdur" (Ahdî, 2018: 240) diyerek Fuzûlî’nin Nevâî tarzına olan yakınlığından bahseder. Ali Nihat Tarlan da; Fuzûlî’nin Şarktaki Çağatay şairlerini ve Garptaki Anadolu şairlerini iyi tanıdığını, Divanı'nın mukaddimesinde bunlardan bahsettiğini söyledikten sonra Leylâ vü Mecnûn'unda "Olmuşdu Nevâî̀-i sühandan / Manzûr-l Şehenşeh-i Horasan” dediğini, bunlardan hiç bahsedilmese dahi Fuzûlî’nin o kadar Nevâî'nin havası içinde yaşadığını ki dil hususiyetleri olmasa bunların birbirinden ayırt etmenin güç olduğunu, söyler (Çetindağ, 2011:254). Eski kaynakların özellikle belirttiği gibi Fuzûlî üzerinde Alî Şir Nevâî’nin ciddi bir etkisi bulunmaktadır.

Bu tartışmanın yanında Fuzûlî’nin Ali Şir Nevâ̂’’nin Leylî vü Mecnûn mesnevisini görüp görmediği de tartışılmaktadır. Nihat Sami Banarlı, Fuzûlî’nin Türkçedeki bu Leylî vü Mecnûn'lardan tamamen habersiz olduğunu, onu lisan1mızda ilk defa yazdığını sanarak harekete geçtiğini ve bu bahtiyar gafletin Türk dili ve edebiyatına Şark'ın bütün Leylî ve Mecnûn'larının en güzelini kazandırdığını belirtir (Banarl1, 1971:551). Fuat Köprülü ise, Fuzûlî’nin Ali Şir Nevâî’nin Leylî vü Mecnûn'unu bilmesine imkan olmadığını, şairin onu Çağatayca addettiği düşünülse bile Osmanlı ve hatta Azeri Türkçesinde kendisinden evvel yazılmış Leylî vü Mecnûn mesnevilerini bilmediğine hükmedilebilineceğini söyler (Köprülü, 1989: 589). Hasibe Mazıoğlu ise bu durumu şöyle izah eder: "Fuzûlî eserini yazarken daha önce yazılmış olan Leylâ ve Mecnûn'ları görmüş ve bunlardan faydalanmıştır. Ancak sebeb-i nazm-1 kitâbda bu hikâyenin Türkler arasında bulunmadığını söylemesi üzerinde durmak gerekir. Nevâ̂’yi okuduğu açıkça bilinen, şiirlerine pek çok nazireler yazan Fuzûlî’nin, Nevâi'nin Leylî vü Mecnûn'unu bilmemesi düşünülemez. Ancak Nevâî'nin eseri Doğu Türkçesi ile yazılmış olduğundan Leylâ ve Mecnûn'un Batı Türkleri arasında bulunmadığını kast etmiş olmalıdır." (Mazıoğlu, 1986: 35) Hasibe Mazıoğlu'nun gerekçelerine ilave olarak, Doğu Türkçesinin bir kolu olan Çağataycanın asırlar boyunca adlandırma sorunu yaşaması, Türk dilinden kabul edilmemesi gibi yaklaşımlar, ${ }^{4}$ -kanaatimizce- Fuzûlî’nin de Nevâî’nin eserlerini görmüş olmasına rağmen 
Leylâ ve Mecnûn hikâyesinin Türkler arasında bulunmadığını söylemesine sebep olmuştur.

\section{Mesnevilerin Özetleri}

3.1. Ali Şîr Nevâî'nin Leylî vü Mecnûn mesnevisi: Arap kabilelerinden birinin çok zengin olan başkanı, oğlu olmadığı için dertlidir. Tanrı'ya yalvarır. Duasını kabul eden Tanrı, ona bir oğul ihsan eder. Çocuğunun adını Kays koyarlar. Dört yaşına gelince Kays’ı okutmak üzere bir üstat bulurlar. Üstadın kabilesinde ulu ve zengin bir adam vardır. Kızı Leylâ'yı okutmak için evlerinden birini ayırarak okul yapar. Kızıyla birlikte kabilenin başka çocukları da orada okurlar. Kays'ın kabilesinde okul olmadığı için babası onu bu okula verir. Kays ile Leylâ burada tanışıp birbirlerini severler.

Kays aşkından deliye dönmüştür. Herkes onu Mecnûn diye çağırır. O, Leylâ diyerek sevgilisinin evinin etrafında dolaşır. Nihayet çöllere düşer. Dedikodulardan sinirlenen Leylâ'nın babası, Mecnûn'un babasına haber gönderir. Bu sözlerden incinen baba, Mecnûn'u zincire vurarak eve hapseder. Az sonra Mecnûn ayağındaki zinciri çıkararak çöle kaçar.

İbn-i Selâm Leylâ'yı görerek âşık olur, onu babasından ister. Babası razı olursa da sabretmesini söyler. Mecnûn'u dua etmesi için Kâbe'ye götürürler. Mecnûn aşkını artırması için Tanrı'ya yalvarır. Babası umudunu keser, Mecnûn da tekrar dağa çıkar. Leylâ için şiirler söyler; geyiklerle arkadaşlık eder.

Nevfel adındaki kahraman bir gün avlanmak üzere dolaşırken Mecnûn'a rastlar. Ona acıyarak evine getirir ve Leylâ'yı alacağını vadeder. Leylâ'nın babasına haber göndererek kızı ister. Babası kızının nişanlı olduğunu ileri sürerek özür dileyince, Nevfel kabileye hücum eder. Savaş başlar; yenileceğini anlayan babası Leylâ'yı öldürmeye karar verir. Bu kararı düşünde gören Mecnûn ağlayarak Nevfel'e yalvarır. Nevfel de savaşı kazanmış olduğu halde düşün doğruluğuna ve Mecnûn'un kerametine inanarak vazgeçer. Mecnûn çölün yolunu tutar. Leylâ'nın kabilesi de korkudan başka yere göç eder.

Mecnûn Zeyd'e rastlar. Leylâ kabilesinin göç ettiğini Zeyd'den öğrenir. Kabilenin eskiden bulunduğu yere giderek dolaşır. Leylâ'nın oturduğu yere yüzünü sürer; kirpikleriyle yeri süpürür, toprağı gözyaşlarıyla 1slatır. O sırada 
uyuz bir köpek görüp köpeğin yüzünü gözünü öper, gömleğini yırtarak yaralarını sarar, ona dert yanar. Sonra yine geyikleriyle buluşmak üzere çöllere döner.

Zeyd, Mecnûn'a Leylâ'dan mektup getirir. Leylâ uzun uzun izdırabını anlattıktan sonra "işittim ki Nevfel'in kızına söz vermişsin” diyerek sitem etmektedir. Mecnûn da verdiği cevapta Leylâ'nın güzelliğini övdükten ve kendinden bahsettikten sonra İbn-i Selâm'1 hatırlatır.

Mecnûn'un hasretine dayanamayan babası onu arayıp bulur, boynuna ip takarak eve getirir. Nevfel'in kızını Mecnûn'a almak ister. Nevfel teklifini kabul eder. Evde yalnız kalan Mecnûn tekrar dağa çıkar.

Mecnûn Leylâ'nın çobanına rastlar. Çobanın verdiği koyun postuna girerek Leylâ'nın kabilesinin bulunduğu yere gider. Mecnûn Leylâ'yı görünce bir âh çekip yere yıkılır; Leylâ' da onun üzerine yıkılır. Leylâ'yı eve götürürler. Çoban da Mecnûn'u aldığı yere götürüp bırakır. Bunu duyan Mecnûn'un babası oğlunu evine getirir. Onu Nevfel'in kızıyla evlendirir. İki genç yalnız kalınca kız başkasını sevdiğini Mecnûn'a itiraf eder. Mecnûn'un hoş görmesi üzerine odadan çıar. Onları gözetleyen Nevfel öfkelenirse de aşkın kudreti karşısında susar.

Aynı gün Leylâ'yı da İbn-i Selâm ile evlendirirler. Leylâ kendini öldürmek için zehirli kılıç hazırlar. Nikâhtan sonra eli kızın eline değince saralı olan İbn-i Selâm hemen yere yıkılır. Öldü sanarak onu başka yere götürürler. Yalnız kalan Leylâ evden çıkarak sessizce yürür. Bu sırada Mecnûn da çölün yolunu tutmuş, Leylâ'nın bulunduğu yere gelmektedir. İkisi karşılaşır. Kucaklaşıp sabaha kadar konuşurlar. Sabah olunca Leylâ kabilesine döner. Mecnûn çölde kalır. Mecnûn, Necd dağında Leylâ'nın kabilesine bakan bir yeri seçip oraya yerleşir. Vahşi hayvanlar ve kuşlarla arkadaşlık eder.

Mecnûn'un annesiyle babası ölür. Mecnûn'un hasretiyle üzgün olan Leylâ, onun annesiyle babasının ölümünü duyunca kendisinin sebep olduğunu düşünerek büsbütün dertlenir. Bu üzüntüyle hastalanır, günden güne solar, ölüm döşeğine düşer. Babasıyla annesinin kabri üzerinde kendinden geçmiş olan Mecnûn, Leylâ'nın halini hatiften gelen bir sezgiyle anlayarak kabilenin bulunduğu tarafa koşar. Kimseden çekinmeyerek evin içine dalıp Leylâ'nın yanına 
girer. O sırada annesine vasiyet etmekte olan Leylâ son sözlerini söylemektedir. Birbirlerine bakışıllar, her ikisi de bir anda ruhlarını teslim eder. Mecnûn'un eve girdiğini görenler koşuşurlar, ikisinin de ölmüş olduğunu görünce şaşırıp kalırlar. İkisini de bir kefene sarıp gömerler. (Çelik, 1996: 21-23)

3.2. Fuzûlî’nin Leylâ ve Mecnûn mesnevisi: Arap kabilelerinden birinin reisinin oğlu olmadığı için üzgündür. Allah'a yalvarır, adaklar adar. Nihayet duası kabul olur. Bir oğlu dünyaya gelir, adını Kays koyarlar. On yaşına gelince Kays'1 sünnet ettirip okula verirler. Okulda kızlar da vardır. Kays, Leylâ'yı görünce ona aşık olur Leylâ da Kays'a aşık olur.

Leylâ ile Mecnûn bir müddet neşe içinde vakit geçirirler. Öyle bir hale gelirler ki kaş ve göz ile birbirleriyle anlaşırlar. Nihayet aralarındaki serüven duyulur. Bunu haber alan Leylâ'nın annesi öfkelenerek kızına çıkışır, sonra nasihat eder. Leylâ her şeyin bittiğini anlayarak inkâr yoluna sapar. Bilmezden gelerek annesini kandırır. Eve kapatılır o da ağlamakla vakit geçirir.

Bir gün Mecnûn arkadaşlarına uyarak Leylâ'yı görmek umuduyla gezmeğe gider. Yolu Leylâ'nın bulunduğu yere düşer. Leylâ da arkadaşlarıyla gezmeğe çıkmıştır. İki sevdalı karşılaşır. Mecnûn Leylâ'yı görünce kendinden geçer. Leylâ da kendini kaybederek bayılır. Arkadaşları yüzüne gül suyu serperek Leylâ'yı ayılttıktan sonra evine götürürler. Mecnûn da ayılıp Leylâ'yı göremeyince deliye döner. Arkadaşlarından özür dileyip çölün yolunu tutar.

Arkadaşları Mecnûn'un halini babasına bildirirler. Kabile reisi oğlunu bulmak üzere yollara düşer. Onu sahrada toztoprak içinde perişan bir vaziyette görünce donakalır, oğluna nasihatler eder. Mecnûn babasını tanımaz. İhtiyar, "ben senin babanım” der. Babası bakar ki oğlu söz anlayacak halde değildir. Ona yalan söyleyerek Leylâ'nın evlerinde misafir olduğunu söyler. Mecnûn Leylâ'nın adını işitince eve gelir. Annesi ve babası Mecnûn'a nasihat ederler. Ancak nasihat da oğullarına fayda vermez.

Babası başka çare kalmadığını anlayınca Leylâ'yı istemek üzere gider. Leylâ’nın babası bunları karşılayarak ziyafet çeker. Fakat teklifi duyunca, "O luna deli (Mecnûn) diyorlar. Deliye benim kızım nasıl layık olur?" diyerek teklifi reddeder. Ancak Kays iyi olduğu takdirde kızını vereceğini söyler. 
Bu cevapla dönen babası, Mecnûn'a durumu anlatır. Mecnûn ise aşk divanesinin âkil olamayacağını söyler. Babası Mecnûn'u bu beladan kurtarmak için Kâbe'ye götürür. Mecnûn ise Allah'tan kendini bir an dahi aşk belasından ayırmaması için dua eder. Bunu işiten babası oğlu için kurtuluş yolu kalmadığını anlayarak ondan umudunu keser.

Çölün yolunu tutan Mecnûn, ulu bir dağa erişir. Orada bir ceylanı avcının elinden kurtarır. Onunla çölleri dolaşır. Birçok ceylan da bunlara katılır. Tuzağa düşmüş bir güvercin görür. Kolundaki inciyi vererek onu da kurtarır. Güvercin Mecnûn'un derdini dinleye dinleye ona o kadar alışır ki geceleri başına yuva yapar, gündüzleri de ona bekçilik eder. Bunu gören vahşi hayvanlarla kuşlar, Mecnûn'un etrafinda toplanırlar.

Öte yandan Leylâ da bir hisara kapatılmıştır. Hiç kimse ile görüşmemekte yanına toplanan genç kızlar onu eğlendirmeğe çalıştıkça o bir yerini kanatarak ağlamak için bahane bulmaktadır.

Bir bahar günü annesi Leylâyı hava almak için çıkarır. Fakat Leylâ hiçbir yere gitmek istemez. Bir bahane ile etrafındaki kızları uzaklaştırarak yalnız kalır. Ağlamağa firsat bulur.

İbn-i Selâm ava çıktığı bir gün Leylâ'yı görerek âşık olur. Hediyeler gönderip kızı babasından ister. Anne ve babası razı olur.

Nevfel adında adalet ve cesaretiyle tanınmış bir kahraman, bir gün Mecnûn'un halk arasında okunan şiirlerini beğenerek sahibini sorar. Serüvenini öğrenince kendini görmek üzere çöle gider. Mecnûn’u vahşi hayvanlarla bir köşede görerek acır ve ona "Vahşi hayvanlar seni ne anlar? Bir isteğin varsa insanlardan iste. Eğer iş para ile biterse onu yük yük verelim, savaş gerekirse kanımızı dökelim. Benden ayrlmazsan sevgiline kavuşursun” der. Mecnûn: "Birçokları benim derdime çare aradılar, ama bulamadılar. Bilirim sende lütuf çoktur. Fakat bende de baht yoktur" der.

Nevfel onu teselli eder. Mecnûn umutlanarak davranır. Nevfel Leylâ'nın kabilesine bir mektup yazar, Leylâyı Mecnûna isteyerek onları tehdit eder. Onlar da aynı şiddetle cevap vererek reddederler. İki taraf savaşa başlarlar. Bir kenarda savaşı seyreden Mecnûn, Leylâ'nın kabilesinin üstün gelmesi için Allah'a yalvarır. Kendi tarafından biri ölünce şükreder. Leylâ askerinden biri ölünce 
dertlenip ağlar. Bunu gören biri: "Biz senin yolunda canımızı veriyoruz. Sen düşmana dua ediyorsun. Bu nasıl iş?" diye sorar. Gece olunca savaşa ara verirler. Mecnûn'un duasını Nevfel'e anlatırlar. Bunu işiten Nevfel: "Eğer galip gelirsem bir daha Leylâ'nın adını anmayayım” der. Sabah olunca savaş tekrar başlar. Nevfel bu sefer galip gelir ve kendi yurduna doğru çıkıp gider. Mecnûn da Nevfel'e sitemler eder.

İbn-i Selâm hediyeler gönderir. Nikâh için hazırlıklar yapılır. Bunu öğrenen Leylâ matem tutar. Meşşatanın yüzüne sürdüklerini gözyaşıyla siler. Düğün biter, herkes dağılır. Leylâ, İbn-i Selâm'la yalnız kalır. İbn-i Selâm Leylâ'nın duvağını kaldırmak ister. Leylâ kurtulmak için kendinde büyü olduğu yalanını söyler. İbn-i Selâm bu yalana inanır.

Zeyd vaktiyle Zeyneb'e âşık olduğu için aşkın cefasını çekmiş birisidir. Leylâ'nın İbn-i Selâm'la evlendiğini duyunca gidip Mecnûn'a haber verir. Bunun üzerine Mecnûn eline kalemi alıp Leylâ'ya sitem dolu mektup yazar. Zeyd ile gönderir. Zeyd mektubu Leylâ'ya vermek için İbn-i Selâm'a sokulur. Kendisinde bulunan bir dua ile Leylâ'yı iyi edeceğini söyler. Böylece Leylâ'nın yanına girerek mektubu verir. Leylâ mektubu okuyunca çok üzülür, hemen cevabını yazar. İbn-i Selâm'ın kendisine yaklaşamadığını, uzaktan bakmakla yetindiğini söyler.

Leylâ'nın babası, kabile reisine şikâyette bulunarak Mecnûn'u öldürmek istediklerini bildirir. Bunu haber alan Mecnûn'un babası çöle giderek oğlunu bulur, ona nasihatler eder, yalvarır. Ancak Mecnûn Leylâ ile iki bedende bir ruh olduklarını söyler. Mecnûn'un babası nasihatten ve sitemden vazgeçer. Son vasiyetini yapıp evine döner ve ölür. Mecnûn, babasının ölümünü duyunca ağlar, hemen mezarına koşup üstüne kapanır.

Mecnûn dağa çıkınca arkadaşı Zeyd'in sevinçle geldiğini görür. Zeyd, Leylâ'y1 gördüğünü söyler. Onun halini anlatarak dert yandığını serbest olmadığ 1 için mektup yazamadığını, fakat kendisinden mektup beklemekte olduğunu anlatır. Mecnûn bunları işitince Leylâ'ya güveni artar. Mektubunu yazıp Zeyd ile Leylâ'ya gönderir. Mecnûn'un âhı tutar. Günden güne sararıp solan İbn-i Selâm ölür. Bu ölüm ile Leylâ mateme girer.

Zeyd, İbn-i Selâm'ın ölümünü Mecnûn'a haber verir. Leylâ annesinin evine gelir ama İbn-i Selâm'ın yasını tutmak bahanesiyle ağlamaktadır. Leylâ'nın kabilesi göç etmeye karar verir. Leylâ bir deveye biner, derdini de deveye açar. 
Deve ile gece giderken yolunu şaşırır. Deveci de fark edemez. Leylâ kendine gelip kaybolduklarını fark edince devesini sağa sola koşturur, kafileyi bulamazlar. Çölde dolaşırlarken Mecnûn'un bulunduğu yere giderler. Önce birbirlerini tan1yamazlar. Leylâ Mecnûn'un artık kemale erdiğini anlar. Leylâ'nın kaybolduğunu anlayan kervandan birisi onu aramaya çıkmıştır. Leylâ'yı çölde bulur, alıp götürür.

Mecnûn'dan uzaklaşan Leylâ artık tesellisini kaybetmiştir ve dünya ile ilişiğini kesmiştir. Allah'a yalvarıp ölümünü ister. Yataklara düşer. Bir müddet sonra ruhunu teslim eder. Leylâ'nın öldüğünü öğrenen Zeyd, haberi Mecnûn'a ulaştırır. Mecnûn haberi alınca Zeyd ile yollara düşer. Leylânın kabrine gelince, kanlı gözyaşlarını akıtarak mezarın toprağını, üstüne başına saçar, Leylâ diyerek can verir. Mecnûn'u yıkayıp Leylâ'nın mezarını açıp onun yanına gömerler.

\section{Mesnevilerin Karşılaştırılması}

\subsection{Yapı Bakımından}

4.1.1. Şekil Bakımından: Ali Şîr Nevâî’nin Leylî vü Mecnûn adlı eseri tamamıyla mesnevi nazım şekliyle yazılmıştır. Ancak Fuzûlî’nin Leylâ ve Mecnûn'u ağırlıklı olarak mesnevi nazım şekliyle yazılmış olmasına rağmen hikâyede başka nazım şekilleri de kullanılmıştır. Bu nazım şekilleri şunlardır: 3 kaside: Toplam 60 beyit (1'i münâcât, 1'i na't, 1'i Kanuni Sultan Süleyman medhiyesi), 26 gazel: Toplam 162 beyit, (Leylâ'nın dilinden 8, Mecnûn'un dilinden 12, Üstadın gazeli 2, münâcât gazel 2 adet) 2 murabba: 26 beyit (Leylâ'nın dilinden 1, Mecnûn'un dilinden 1 adet) Hikâyenin tamamı 3098 beyitten oluşmaktadır. Bu durumda, tamamına göre gazel nazım şekliyle yazılan beyitler; \%5.22, kaside ile yazılan beyitler; \%1.93, murabba ile yazılan beyitler; $\% 0.83$, mesnevi nazım şekli ile yazılanlar ise $\% 92.02$ oran teşkil etmektedir. Fuzûlî’nin eserinin başında, içinde 3 bend murabba olan mensur bir de dibâce bulunmaktadır. Fuzûlî’nin Leylâ ve Mecnûn mesnevisinde birden çok nazım şeklinin kullanılması, bir anlatma tekniği olmasından öte aynı zamanda duygu ve düşüncelerin kesafet kazandığı birer metin olma özelliğini kazandırır. Fuzûlî’nin eserini yüzylllar boyunca rakipsiz kılan ve şaheser seviyesine yükselten de, eser içine şuurlu bir şekilde serpiştirilmiş olan gazellerdir. (Çapan, 2005:227; Turan, 2017:151-249) 
Nevâî’nin eseri 38 bölümden oluşur. İlk bölüm 75 beyitlik bir tevhiddir. II. bölüm bir münâcât, III. bölüm bir na’t, IV. bölüm sebeb-i te’lif, V. bölüm söz gevheri vasfinda, VI. bölüm Mevlânâ Nureddin Abdurrahman Câmî medhiyesi, VII. bölüm Şah’ın medhi, VIII. Sultan Hüseyin Bahadır Han’a niyaz arzından sonra, IX. bölümde asıl hikayeye geçilir.

Fuzûlî’nin Leylâ ve Mecnûn'u ise 113 bölümden oluşur. İlk bölüm mensur bir dibâce, II. bölüm, Yüce Allah'a hamd, III. bölüm tevhid, IV. bölüm, münâcât, V. bölüm kaside nazım şekliyle yazılan münâcât, VI. bölüm Allah'ın varlığını isbat eden bölüm, VII. bölüm cehaletini itiraf, VIII. bölüm, Hz. Peygamber'e na’t, IX. bölüm mi'raciye, X. bölüm kaside-na’t, XI. bölüm özür beyan etme, XII. bölüm İslam Padişahı'na dua, XIII. bölüm Asrın Padişahı'na övgü, XIV. bölüm Padişah’a kaside, XV. bölüm, kitabın yazılma sebebi, XVI. bölüm, Beğ hazretlerini övgü, XVII. bölüm ise sevgi fermanının tuğrası ve meşakkat divanının önsözü olup bu bölümde asıl hikâyeye geçilir.

4.1.2. Vezin Bakımından: Ali Şîr Nevâî’nin Leylî vü Mecnûn mesnevisi, bahr-1 hezec-i müseddesin "mef' û lü mefâ'ilün fe 'ûlün”'kalıbıyla yazmıştır.

Serv olmay mihnetidin âzâd

Kalmay şimşâd derdidin şâd (Beyit: 954)

Fuzûlî de mesnevisini -aynı Nevâî gibi- bahr-1 hezec-i müseddesin "mef 'û lü me fâ ‘i lün fe 'û lün” kalıbıyla yazmıştır. Bu kalıp sekt-i melih kalıbı olduğu için zaman zaman sekt-i melihi Fuzûlî de yapmıştır.

Ey mebde-i feyz-i âferîniş

Senden rûşen çerâg-1 bîniş

Ey perde-i mâsivâ nikâbun

Senden özge senün hicâbun (Beyit: 28-29)

Diğer yandan Fuzûlî’nin eserinde, mesnevi nazım şeklinin dışında başka nazım şekilleri de bulunmaktadır. Bu nazım şekilleri ve yazıldıkları vezinler şöyledir: 


\section{Kasideler:}

Fâ 'i lâ tün fâ 'i lâ tün fâ 'i lâ tün fâ 'i lün ( 1 adet, s.354)

Mef 'û lü fâ i lâ tü me fâ 'î lü fâ i lün (1 adet, s.72)

Me fâ 'î lün me fâ 'î lün me fâ 'î lün me fâ 'î lün ( 1 adet, s.92)

\section{Leylâ'nın gazelleri:}

Fe 'i lâ tün fe 'i lâ tün fe 'i lâ tün fe 'i lün ( 3 adet, s. 148, 264, 306)

Me fâ 'i lün fe 'i lâ tün me fâ 'i lün fe 'i lün ( 1 adet, s.324)

Me fâ î lün me fâ îlün me fâ î lün me fâ îlün ( 2 adet, s. 428, 494)

Fâ 'i lâ tün fâ 'i lâ tün fâ 'i lâ tün fâ 'i lün (2 adet, s.472, 480)

\section{Levlâ'nın murabbaı:}

Me fâ î lün me fâ îlün me fâ îlün me fâ îlün ( 1 adet, s. 366)

\section{Mecnûn'un gazelleri:}

Fâ 'i lâ tün fâ 'i lâ tün fâ 'i lâ tün fâ 'i lün ( 7 adet, s.160, 198, 444, 466, $474,502,530)$

Fe 'i lâ tün fe 'i lâ tün fe 'i lâ tün fe 'i lün (1 adet, s.312)

Me fâ îlün me fâ îlün me fâ îlün me fâ îlün (3 adet, s.176, 280, 488)

Mef 'û lü fâ i lâ tü me fâ 'î lü fâ i lün (1 adet, s. 216)

\section{Mecnûn'un murabbal:}

Fâ 'i lâ tün fâ 'i lâ tün fâ 'i lâ tün fâ 'i lün (1 adet, s.354)

\section{Üstadın gazelleri:}

Mef 'û lü me fâ î lü me fâ î lü fe 'û lün (1 adet, s.190)

Me fâ îlün me fâ îlün me fâ îlün me fâ îlün ( 1 adet, s. 518)

\section{Münâcât gazelleri:}

Mef 'û lü fâ 'i lâ tü me fâ 'î lü fâ i lün ( 2 adet, s. 420, 454)

4.1.3. Kafiye Bakımından: Fuzûlî ve Nevâî’nin mesnevilerinde kafiye olan kelimeler Türkçe, Arapça ve Farsça kökenli kelimeler olmakla beraber, Türkçe, Arapça ve Farsça karışık olarak yapılmış örneklerine de çokça rastlanmaktadir. 


\section{Fuzûlî’de:}

Türkçe kelimelerle yapılanlara örnekler:

Endîşe-i zât kılmak olmaz Bilmek bu yeter ki bilmek olmaz (Beyit:48)

Eşyâda egerçi râz çohdur $\quad$ Ol kim ola râzun anda yohdur (Beyit:53)

Farsça kelimelerle yapılanlara örnekler:

Ger cân ise hâk-i dergehündür V'er akl ise sâlik-i rehündür (Beyit:57)

Râh-1 talebünde bî-karârem Ammâ talebümde şerm-sârem (Beyit:67)

Arapça kelimelerle yapılanlara örnekler:

Munda yete rütbe-i kemâle Anda yete devlet-i visâle (Beyit:87)

Evvelde çü lutfun oldı ma'lûm Âhir günde hem etme mahrûm (Beyit:90)

\section{Karışık olanlar:}

(Türkçe-Farsça)

Düşmenlige dûstlig k1lup ad Tedbîr-i necâtum eylemen yâd

(Beyit:1006)

(Farsça-Arapça)

Islâhuma eylemen teemmül Kim gül tiken olmaz ü tiken gül (Beyit: 993)

\section{(Arapça-Türkçe)}

Ebrû-yı ham ise ger murâdun Süst etme kemân-1 i'tikâdun (Beyit: 947) 


\section{Ali Sîr Nevâî'de:}

Türkçe kelimelerle yapılanlara örnekler:

Bî-hâl kabîlesiga ketti Gamdın anga yetti olça yetti

(Beyit: 940)

Sagındı kaçan nezâre kıldı Kim çerh üyi başıga yıkıldı

(Beyit: 963)

Farsça kelimelerle yapılanlara örnekler:

Çün derdiga tapmadı kerâne Derd eşkini eyledi revâne (Beyit:964)

Çün boldı libâsı âteş-âlûd Gerdûnga yetişti âhı dek dûd (Beyit:967)

Arapça kelimelerle yapılanlara örnekler:

Köksi ara şu'le-yi firâkı $\quad$ Bu ot bile dâg-1 iştiyâkı (Beyit: 975)

Bî-dil körüben yaruk cihânı Çekti yene âh ile figânı

(Beyit: 986)

Karışık olanlar:

(Farsça-Türkçe)

Hoşrak buzuk anga hân-mândın Lîkin özi köp buzugrak andın (Beyit:2385)

\section{(Arapça-Farsça)}

Sening tening olsa yâre gamdin Mening cigerim bolur elemdin (Beyit: 2411)

\section{(Arapça-Türkçe)}

Kem bolmagay el içindin atım Bî-gânega kalmagay cihâtım (Beyit: 2429)

4.1.4. Redif Bakımından: Fuzûlî’nin mesnevisinde -tespitlerimize göregenel olarak redif az kullanılmıştır. Örnekleme metoduyla aldığımız 1201. beyit ile 1300. beyit arasında sadece 44 beyitte redif (\% 44) bulunmaktadır. Bunların 10 tanesi ek+kelime tekrarı, 34 tanesi ek ile oluşmuş rediflerdir. 
Başum tügin âşiyâne kılgıl

(Beyit: 1204)

Gör hecr-i ruhında 1ztırâbum

(Beyit: 1206)
Göz yaşumı âb ü dâne k1lg1l

Peygâmum ilet getür cevâbum

Ali Şîr Nevâî’nin mesnevisinde de, örnekleme metoduyla aldığımız 1201. beyit ile 1300. beyit arasında 40 tane redifin (\%40) olduğu tespit edilmiştir. Bunlardan 14 tanesi ek+kelime tekrarı, 26 tanesi ise ek ile oluşmuş rediflerdir.

Bolmış barıdın ferâgı gûyâ

Habt etmiş anıng dimâgı gûyâ

(Beyit: 1231)

Ne erkin anıng atası hâli Bî-çâre anasınıng melâli

(Beyit: 1240)

\section{2. Konu Bakımından}

4.2.1. Vak’a Farklılıkları: Ali Şîr Nevâî'nin eserinde ise; Leylâ'nın babası kızı için bir ev ayırır, burasını okul yapar. Kızıyla birlikte kabilenin başka çocukları da orada okurlar. Kays'ın kabilesinde okul olmadığı için babası dörtbeş yaşında onu bu okula verir ve okutması için bir üstat bulur.

yetkeç yaşı tört ü beş arası ta'lim sözin salıp atası (Beyit: 668)

Fuzûlî’nin eserinde; Kays on yaşına gelince sünnet ettirilir. (Beyit:550) Sünnet işi bittikten sonra sıra ilim öğrenmesine gelir. Kays’1 hazırlayıp mektebe verirler. (Beyit:557- 558)

İki eser arasında Kays’ın okula verilme yaşında fark vardır. Ayrıca Nevâî' de sünnet olması olayı yoktur. Fuzûlî’nin eserinde Kays ve Leylâ herhangi bir okula verilir. Nevâî' de ise bu okul Leylâ'nın babasının yaptırdığı bir okuldur. Nevâî'nin eserinde; Leylâ'nın Kays’a olan aşkının başlaması, Leylâ’nın hastalanıp okula gelememesi, bir müddet sonra iyi olup gelmesi ve onun geldiğini gören Kays'ın ağlaması üzerine Leylâ'nın Kays'ın kendini sevdiğini anlar. Fuzûlî’nin eserinde ise bu bölüm; Kays okulda ilk defa görünce kendinden geçer. Leylâ'da Kays'1 görünce bin zevk bulup özünü kaybeder.

Nevâî'nin mesnevisinde, Kays'ın Leylâ'ya olan aşkının dedikodusundan dolayı, Leylâ'nın babası Kays'ın babasına haber gönderir. Bu sözlerden incinen baba, Mecnûn'u zincire vurarak eve kapatır. Mecnûn 1zdırap içindedir. Nihayet ayağından zinciri çıkararak çöle kaçar. 
Fuzûlî'de ise, Mecnûn arkadaşlarıyla gezmeğe gittiğinde Leylâ'yı görür. Mecnûn kendinden geçer, Leylâ da bayılır. Arkadaşları Leylâ'yı evine götürürler. Mecnûn ayılıp onu göremeyince deliye döner. Babasını hatırlayıp ona bir gazel yazar ve çöle düşer.

Nevâî'de, Mecnûn'un babasının Leylâ'yı istemesi söz konusu değildir. Ancak Fuzûlî’nin eserinde ise, Mecnûn'un babası Leylâ'yı oğluna ister. Leylâ'nın babası önce iyi karşılar ama niyetlerini anlayınca "deliye benim klzım nasıl layık olur" diyerek onları geri çevirir. Ancak Kays iyi olduğu takdirde kızını vereceğini söyler. Bunun üzerine babası oğlunun tedavisi için her türlü yola başvurur.

Nevâî'de; İbn-i Selâm, Leylâ'yı görüp âşı olur, onu babasından ister. Leylâ'nın babası da razı olur. Fakat sabretmesini söyler. Fuzûlî’de aynı imge aynı şekilde vardır. Aralarında fark yoktur. Nevâ̂̂'de İbn-i Selâm'la nişanlanma olayı Mecnûn'un Kâbe'ye gitmesinden önce, Fuzûlî̀de ise Mecnûn'un Kâbe'ye gitmesinden sonra, Mecnûn'dan ümit kesildikten sonra gerçekleşir. Vak'alar, takdim ve tehir edilmiştir.

Nevfel'in kahramanlığı her iki mesnevide aynıdır. Mecnûn ile karşılaşmaları; Nevâî'de, ava çıktığında tesadüfen, Fuzûlî'de ise Nevfel, Mecnûn'un hikâyesini duyması ve onunla tanışmak istemesinden kaynaklanır. Ancak ikisinde de karşılaşma dağda, av esnasında gerçekleşir. Nevâi' de, Nevfel Mecnûn'a: "Leylâ'yl sana isteyeyim. Hediye ile olmazsa onu sana zorla alayım. Ĕger o da olmazsa benim oğlum ol" diye teklif eder. Leylâ'nın babasından kızını Mecnûn'a vermesi için haber gönderir. Ancak Leylâ'nın babası kızının nişanlı olduğunu söyleyerek reddeder. Bunun üzerine Nevfel, Leylâ'nın kabilesine saldırır. Fuzûlî’nin mesnevisinde ise, Nevfel, Leylâ'nın kabilesine mektup yazarak kızı Mecnûn'a ister ve tehdit eder. Aynı şiddetle ret cevabı alınca Leylâ'nın kabilesine saldırır.

Savaşın sona ermesi: Nevâî'de, Leylâ'nın babası kabilesinin yenileceğini anlayınca kızını öldürmeye karar verir. Nevfel'in tarafi kazanır. Mecnûn sevgilisine kavuşacağını düşünerek sevinir. Leylâ’nın kabilesinin yenilmesine ise üzülür. Ancak o gece rüyasında Leylâ'yı görür. Leylâ, babasının kararını gözyaşları içinde anlatır. Mecnûn bağırarak uyanır. Bu işten vazgeçmesi için 
Nevfel'e yalvarır. Nevfel rüyanın doğruluğuna ve Mecnûn'un kerametine inanarak vazgeçer, Mecnûn da çölün yolunu tutar. Leylâ'nın kabilesi, Nevfel'in savaşı kazanmasına rağmen birdenbire vazgeçmesinden kuşkulanır. Bunun bir hile olabileceğini düşünerek, hac bahanesiyle başka yere göç ederler.

Fuzûlî’ de bu bölüm şöyledir: İki taraf dövüşürken Mecnûn bir kenarda savaşı seyr eder. Leylâ'nın kabilesinin galip gelmesi için dua eder. Nevfel tarafından biri ölünce ise şükreder. Bunu gören biri: "Biz senin yoluna canımızı veriyoruz. Sen düşmana dua ediyorsun. Bu nasıl iş?” diye çıkışır. Nevfel de bir türlü galip gelemez. Mecnûn'un duasını Nevfel'e anlatırlar. Ertesi günü Nevfel gâlip gelir. Leylâ'nın babası Nevfel'e yalvararak, kızının nişanlı olduğunu söyleyip bir kadına iki erkek ayıp değil mi diye sorar. Nevfel de, giriştiği bu işten pişman olduğunu, bir hasta için şifa dilediğini, fakat bu hastalığın ilacı olmad1ğını söyleyerek savaşı bırakır, orayı terk eder.

Nevâ̂'’nin mesnevisinde; Mecnûn yolda Zeyd'e rastlar. Onun kederli halininin sebebini sorar. Zeyd de Leylâ'nın kabilesinin başından geçenleri anlatır. Bu arada kendisinin de hırpalandığını söyler. Mecnûn atından inerek onu kucaklar, ağlayarak teselli eder. Varını yoğunu ona vererek Leylâ'ya selâm gönderir. Daha sonra Leylâ'nın kabilesinin bulunduğu yere gider. Mecnûn her tarafi dolaşır. Leylâ'nın bulunduğu yerleri gözyaşlarıyla 1slatır, kirpikleri ile süpürür. Bu sırada orada uyuz bir köpek görür, ona yüzünü, gözünü sürer. Sonra çöle döner. Bu sahne Fuzûlî de ise şöyledir: Zeyd ile tanışması daha sonradır. Yolda bir Efendi'nin kölesini zincire vurup götürdüğünü görür. Esire acıyarak Efendi'sinden onu ister. İhtiyar Efendi, bunun bir dilencilik oyunu olduğunu söyler. Bunun üzerine Mecnûn, köle yerine kendini zincire bağlatır. Gezmeye başlarlar. Leylâ'nın bulunduğu evin önüne gelirler. Bir ah çekip yere düşer. Bunu duyan Leylâ fırlayıp evinden çıkar. Mecnûn'un yanına koşar. Leylâ;

Yâr rahm itdi meger nâle vü efgânımıza

Ki kadem basdı bugün külbe-i ahzânımıza matla'lı gazeli okur. Mecnûn da cevap verir. Görüşürler. Sonunda

Mecnûn;

Küfr-i zülfün salalı rahneler imânımıza

Kâfir ağlar bizim ahvâl-i perişânımıza 
matla'lı gazelini okuyup zincirlerini kırar ve tekrar çöllere düşer. Mecnûn bir günde âmâ gibi gezerek Leylâ'nın mahalline varır. Ancak bu özellikler Nevâî'de yoktur. Çünkü Nevâî’nin eserine göre Leylâ'nın kabilesi savaşın ardından yer değiştirmiştir.

Nevâ̂'’ de Leylâ, İbn-i Selâm ile Mecnûn da Nevfel'in kızı ile nişanlanır. Mecnûn Nevfel'in kızı ile sonunda evlenir. Ancak ilk gece kızın başka birini sevdiği öğrenir. Mecnûn kıza dua ederek orayı terk eder. Bunu öğrenen Nevfel, kızın dürüstlüğü karşısında bir şey diyemez. Mecnûn'un babası buna çok üzülür. Nevfel onu da teselli eder. Aynı gün Leylâ da İbn-i Selâm ile evlenir. Leylâ kendini öldürmek ister. Nikâhtan sonra eli Leylâ'nın eline değen İbn-i Selâm düşüp yere yıkılır. Öldü sanarak başka bir eve götürülür. Yalnız kalan Leylâ evden dışarı çıkıp sessizce yürür. Aynı gece dışarı çıkan Mecnûn ile yolda karşılaşırlar. O gece sabaha kadar konuşurlar. Sabah Leylâ evine, Mecnûn da çöllere döner.

Fuzûlî'de ise; Mecnûn'un evlenmesi vak'ası yoktur. Ancak Leylâ, İbn-i Selâm ile evlenir. İbn-i Selâm, Leylâ'nın duvağını kaldırınca Leylâ bir peri yalanı uydurur. Sabretmesini söyler. İbn-i Selâm bu yalana inanır. Bu derde ilaç bulmak için başvurmadığ çare kalmaz. Zeyd ise Leylâ'nın evlendiğini Mecnûn'a haber verir. Mecnûn bir mektup yazarak Leylâ'ya gönderir. Zeyd, Leylâ'yı iyi edeceğini söyleyerek mektubu Leylâ'ya verir. Leylâ, İbn-i Selâm'ın sadece uzaktan baktığını söyler. Leylâ'nın mektubu da Mecnûn'a ulaşır. Mecnûn sevinir.

Anne-babanın ölümü: Nevâî'de; Mecnûn'un babası ölür, annesi de buna dayanamayarak can verir. Her ikisinin ölümünü rüyasında gören Mecnûn, onların mezarlarını arayıp bulur, ağlar, yanıp yakılır ve orada yığılır kalır.

Fuzûlî'de ise; Leylâ'nın babası, kabile başkanına Mecnûn'u şikayet eder, öldürülmesine karar verilir. Bunu haber alan Mecnûn'un babası, oğlunu arayıp bulur, ona çok nasihatler eder, yalvarır. Mecnûn'un bu esnada kolundan kan fişkırır. Baba, bunun vahdet eseri olduğunu anlar, siteminden vazgeçer ve umudunu kaybeder. Ağlaya ağlaya evine döner ve vefat eder. Mecnûn babasının ölümünü duyunca içi yanıp ağlar, hemen mezarına koşup üstüne kapanır.

Leylâ ve Mecnûn'un ölümü: Nevâînnin mesnevisinde; Leylâ, Mecnûn'un 
anne ve babasının ölümüne kendinin sebep olduğunu düşünür ve çok üzülür. Bu hastalıktan sararıp solar. Ölüm döşeğinde annesine vasiyet ederek, Mecnûn eğer gelirse ona saygıda kusur etmemesini söyler. Bu durum Mecnûn'a hatiften duyurulur. Hemen Leylâ'nın kabilesine koşar. Leylâ'nın evini bulup içeri girer. O esnada Leylâ ruhunu teslim etmek üzeredir. Birbiriyle bakışırlar ve ikisi aynı anda ruhunu teslim eder. İkisini bir kefene sarıp tabuta konur ve öylece defnedilirler.

Fuzûlî' de ise; Mecnûn çöllerde iyice vahdete ulaşmıştır. Leylâ'yı dahi tanımaz durumdadır. Buna çok üzülen Leylâ, yataklara düşer. Annesine vasiyet eder. Sonra da ölür. Leylâ’nın öldüğünü Mecnûn'a Zeyd haber verir. Mecnûn, Leylâ'nın mezarının başına koşar ve "Leylî dedi verdi cân-ı şîrîn / Ol âşık-ı bîkarâr ü miskin" diyerek vefat eder. Mecnûn'un öldüğünü anlayanlar, haline bakıp ağlarlar. Mecnûn'u yıkayıp Leylâ'nın mezarını açıp onun yanına gömerler.

4.2.2. Birinde Olup Diğerinde Olmayan Vak'alar: Nevâ̂’’nin mesnevisinde, Mecnûn'un babasının Leylâ'yı istemesi söz konusu değildir. Fuzûlî̀'de ise Mecnûn'un babası Leylâ'yı oğluna ister.

Nevâî'nin mesnevisinde; Mecnûn yolda Zeyd'e rastlar. Onun kederli halinin sebebini sorar. Zeyd de Leylâ'nın kabilesinin başından geçenleri anlatır. $\mathrm{Bu}$ arada kendisinin de hırpalandığını anlatır. Mecnûn atından inerek onu kucaklar, ağlayarak teselli eder. Varını yoğunu ona vererek Leylâ'ya selam gönderir. Daha sonra Leylâ'nın kabilesinin bulunduğu yere gider. Mecnûn her tarafı dolaşır. Leylâ'nın bulunduğu yerleri gözyaşlarıyla ıslatır, kirpikleri ile süpürür. Bu sırada orada uyuz bir köpek görür, ona yüzünü, gözünü sürer. Sonra çöle döner. Bu hikâye Fuzûlî’nin mesnevisinde yoktur.

Fuzûlî'de; Mecnûn'un evlenmesi motifi yoktur. Nevâ̂̀'de ise Mecnûn Nevfel'in kızıyla evlenir.

Nevâî'de; Mecnûn'un babası ile annesi de peşpeşe can verirler. Fuzûlî’ de ise annenin ölümünden bahsedilmez.

Nevâî’nin eseri, Mecnûn'un ölümü ile biter. Fuzûlî’nin eseri hemen bitmez. Mecnûn'un ölümünden sonra Zeyd bir güzel rüya görür. Bu rüyayı halka anlatır ve halkın imanı artar. Leylâ ile Mecnûn'un kabirlerini ziyaret, adet haline gelir. 
Nevâî'nin mesnevisinde; İbn-i Selâm'ın ölmesi, Leylâ'nın kabilenin adetlerine uyarak mateme girmesi, bunu duyan Mecnûn'un sevineceği yerde âh edip ağlamas1, Leylâ'nın annesinin evine gelmesi, İbn-i Selâm'ın ölümünü bahane ile mateme devam etmesi, kafile ile beraber yolculuk yaparken Leylâ'nın devesinin çölde kaybolması, devenin Mecnûn'un yanına gitmesi, Mecnûn'un Leylâ'yı tanıyamaması, Leylâ'nın vuslat teklifini Mecnûn'un reddetmesi, Mecnûn'un manevî olgunluklara erişmesi ile ilgili motifler ve bunları işleyen olaylar bulunmamaktadır.

\section{Sonuç}

1. Karşılaştırmalı Edebiyat çalışmaları farklı kültürlere mensup edebî eserler arasında olacağı gibi aynı dil ile yazılan edebî eserler arasında da yapılmaktadır. Bu çalışmaların çıkış noktası başta klasik eserler olmak üzere insanlığın ortak kültür hazinelerini teşkil eden edebî eserlerdeki müşterek noktaları tespit etmek, dönemlere ve edebî türlere göre karşılaştırarak özellikle ulusal edebiyatların güçlenmesini ve gelişmesini sağlayacak şekilde başka ülkelere, dillere ait edebiyatlardan istifade etmektir. Edebî eserler genel olarak konu, düşünce ve biçim açısından karşılaştırılmalıdır.

2. Leylâ ve Mecnûn hikâyesinin aslı Arap edebiyatında ortaya çıkmış, oradan Fars, Türk ve Urdu edebiyatlarına geçmiştir. Bu edebiyatlarda çok zengin bir şekilde işlenilmiş ve işlenilmeye de devam etmektedir.

3. Türk edebiyatında ilk defa bu hikâyeden bahseden Gülşehrî'dir. Onu Âşık Paşa takip eder. Fakat müstakil olarak ilk Leylâ ve Mecnûn hikâyesini işleyen Edirneli Şâhidî olup eserini 1479'da yazmıştır. Ali Şîr Nevâî 1484'te, Fuzûlî ise 1537'de mesnevilerini tamamlamışlardır.

4. Nevâî’nin eserinin tamamı mesnevi nazım şekliyle yazılırken, Fuzûlî, eserinin \%92'sini mesnevi nazım şekliyle, geri kalan kısımları ise kaside, gazel ve murabba nazım şekilleriyle yazmıştır.

5. Nevâî ve Fuzûlî mesnevilerinde "mef 'û lü me fâ 'i lün fe 'û lün" kal1bını kullanmışlardır. Fuzûlî mesnevisindeki diğer nazım şekillerini çeşitli aruz kalıpları ile yazmıştır. 
6. Her iki mesnevide de konu bakımından vak'a farklılıkları çoktur. Leylâ ile Mecnûn'un okula başlamaları, Kays'ın sünnet olması, okul yılları, Leylâ'nın okuldan alınması, Kays'ın zincire vurulması, Mecnûn'un babasının Leylâ'yı oğluna istemesi, İbn-i Selâm'ın hikayeye dahil olması, Leylâ ile nişanlanmas1, Mecnûn'un Kâbe'ye gidip dua etmesi, Nevfel'in Mecnûn'a Leylâ'y1 istemesi, reddedilmesi, yapılan savaş, savaşın sona ermesi, buradaki motifler, Zeyd'in ortaya çıkması, Leylâ ile İbn-i Selâm'ın evlenmesi, düğünden sonra yaşananlar, İbn-i Selâm'ın ölmesi, anne ve babanın ölümü, sonunda Leylâ ile Mecnûn'un ölümü olayları her iki mesnevide de olup ancak farklı kurgulanmışlardır.

7. Birinden olup diğerinde olmayan vak'alar da bulunmaktadır. Özetle; Mecnûn'un babasının Leylâ'yı oğluna istemesi, İbn-i Selâm'ın ölmesi, Leylâ'nın kabilenin adetlerine uyarak mateme girmesi, bunu duyan Mecnûn'un sevineceği yerde ah edip ağlaması, Leylâ'nın annesinin evine gelmesi, İbn-i Selâm'ın ölümünü bahane ederek ağlaması, kafile ile beraber yolculuk yaparken Leylâ'nın devesinin çölde kaybolması, devenin Mecnûn'un yanına gitmesi, Mecnûn'un Leylâ'yı tanıyamaması, Leylâ'nın vuslat teklifini Mecnûn'un reddetmesi, Mecnûn'un manevi olgunluklara erişmesi, Mecnûn'un ölümünden sonra Zeyd'in bir güzel rüya görmesi, bu rüyayı halka anlatması, Leylâ ile Mecnûn'un kabirlerini ziyaret yeri haline gelmesi olayları Nevâ̂̀'nin mesnevisinde yoktur. Mecnûn'un yolda Zeyd'e rastlaması, Zeyd'in Leylâ'nın kabilesinin başından geçenleri anlatması, Mecnûn'un atından inerek onu teselli etmesi, Leylâ'nın kabilesinin bulunduğu yere gitmesi, Mecnûn'un her tarafı dolaşması, Leylâ'nın bulunduğu yerleri gözyaşlarıyla ıslatıp kirpikleri ile süpürmesi, uyuz bir köpeği görüp ona yüzünü, gözünü sürmesi, çöle dönmesi, Nevfel'in kızıyla evlenmesi, Mecnûn'un babası ile annesinin peşpeşe can vermesi olayları da Fuzûlî’nin mesnevisinde bulunmamaktadır.

8. Her iki mesnevide de ortak konu ve kahramanlar çok olmasına rağmen farklılıklar da mevcuttur. Vak'alar bakımından, Fuzûlî’nin mesnevisi, Nevâî'nin mesnevisinden daha fazla vak'aya sahip olduğu görülmektedir.

9. Yapılan araştırma ve incelemelerin neticesinde; Fuzûlî'nin Nevâî’nin mesnevisini gördüğünü, ondan da beslendiğini ama model olarak almadığını söylemek mümkündür. 


\section{Kaynakça}

Ahdi (2018), Gülşen-i Şu'arâ, Haz. Süleyman Solmaz, ekitap.ktb.gov.tr, erişim tarihi: 10.10.2019.

Akalın, Nazir (1997), “Nizami-yi Gencevi ile Fuzuli-yi Bağdadi’nin Leyli u Mecnun Mesnevilerinin Tartışmalı Mukayesesi” Türkiyat Araştırmaları Dergisi, S.3, Konya.

Ali Şîr Nevâî (1996), Leylî vü Mecnûn, Haz: Ülkü Çelik, Ankara.

Aytaç, Gürsel (1997), Karşılaştırmalı Edebiyat Bilimi, Ankara.

Banarlı, N. Sami (1971), Resimli Türk Edebiyatı Tarihi, C.1, İstanbul.

Bayram, Yavuz (2004), "Karşılaştırmalı Edebiyat Bilimi ve Bir Uygulama” Selçuk Üniv., Türkiyat Araştırmaları Enstitüsü, Türkiyat Araştırmaları Dergisi, S. 6, Güz.

Çapan, Pervin (2005), “Ali Şîr Nevâî ve Fuzûlî’nin Leylâ ve Mecnûn Mesnevilerinin Anlatım Tarzlarının Mukayeseli Tahlili”, I. Uluslararası Karşılaştırmalı Edebiyat Kongresi, 15-17 Ekim 2003, Eskişehir Osmangazi Üniv. Basımevi, Eskişehir.

Çetindağ, Yusuf (2011), Ali Şîr Nevâî, İstanbul.

Durmuş, İsmail (2003), "Leylâ ve Mecnûn” TDVİA, C. 27, İstanbul.

Ercilasun, Ahmet Bican (2011), Başlangıçtan Yirminci Yüzyıla Türk Dili Tarihi, Ankara.

Fuzûlî (2004), Leylâ ve Mecnûn, Haz: Muhammet Nur Doğan, İstanbul.

Karayazı, Nurgül (2007), Fuzûlî’nin Leylâ ve Mecnûn'unda Tasavvufi Kavram ve Unsurlar, Marmara Üniv., Sosyal Bilimler Enst. İstanbul.

Kartal, Ahmet (2013), Doğu'nun Uzun Hikâyesi Türk Edebiyatında Mesnevi, İstanbul.

Kefeli, Emel (2006), “Karşılaştırmalı Edebiyat: Tanım, Yöntem ve İncelemeler,” Türkiye Araştırmaları Literatürü Dergisi, (TALİD) C.4, S. 8.

Köprülü, M. Fuad ((1989), Edebiyat Araştırmaları, C.II, İstanbul.

Latîfî (2000), Tezkiretü'ş-şu'ara ve tabsıratü’n-nuzamâ, Haz. Rıdvan Cânım, Ankara.

Levend, Agah Sırrı (1959), Arap, Fars ve Türk Edebiyatlarında Leylâ ve Mecnûn Hikayesi, Ankara.

Mazıoğlu, Hasibe (1956), Fuzûlî-Hafız, Ankara.

Mazıoğlu, Hasibe (1986), Fuzûlî ve Türkçe Divanı'ndan Seçmeler, Ankara.

Turan, Lokman (2017), Mesneviyi Gazelle Okumak, İstanbul.

Uçan Eke, Nagehan (2013), “Klasik Türk Edebiyatında Metinler Arasılık Alanında Bibliyografya Denemesi ve Hasibe Mazıoğlu'nun Fuzûlî-Hafız Örneği” Turkish Studies, S.8/1.

Ünver, İsmail (1986), “Mesnevî”, Türk Dili Divan Şiiri Özel Sayısı, S.415,416,417, Ankara. 